\title{
Contributions towards an understanding of the Atomariinae (Coleoptera, Cryptophagidae) of Atlantic Canada
}

\author{
Christopher G. Majka', Colin Johnson², David W. Langor ${ }^{3}$ \\ I Nova Scotia Museum, 1747 Summer Street, Halifax, Nova Scotia, Canada B3H 3 A6 217 Peaknaze Close, \\ Glossop, Derbyshire, England SK 13 GUN 3 Canadian Forest Service Northern Forestry Centre, 5320 - 122 \\ St. NW, Edmonton, Alberta, Canada T6H $3 S 5$
}

Corresponding author: Christopher G. Majka (c.majka@ns.sympatico.ca)

Academic editor: Michael Thomas | Received 12 November 2009 | Accepted 18 January 2010 | Published 2 February 2010

Citation: Majka CG, Johnson C, Langor DW (2010) Contributions towards an understanding of the Atomariinae (Coleoptera: Cryptophagidae) of Atlantic Canada. ZooKeys 35: 37-63. doi: 10.3897/zookeys.35.318

\begin{abstract}
The Atomariinae (Coleoptera: Cryptophagidae) fauna of Atlantic Canada are surveyed. Ten species in the genus Atomaria are reported in the region, six of which, including Atomaria distincta Casey, Atomaria fuscata Schönherr, Atomaria lederi Johnson, Atomaria lewisi Reitter, Atomaria testacea Stephens, and Atomaria nigrirostris Stephens, are newly recorded in Canada. Atomaria lederi and A. lewisi are newly recorded in North America. Twenty-three new provincial records are reported. Atomaria curtula Casey, 1900 (syn. n.) is designated as a synonym of Atomaria lewisi Reitter; Atomaria ovalis Casey, 1900 (syn. n.) is designated as a synonym of Atomaria apicalis Erichson, 1846; and Atomaria saginata Casey, 1900 (syn. n.) is designated as a synonym of Atomaria fuscata Schönherr. A key to species is provided, as are species descriptions. Records of all species are given and their distribution in the region is plotted. The global distribution of all Holarctic and adventive species is briefly summarized, and the jurisdictions in North America where they have been reported are compiled. Habitat and bionomic information is also provided for all species, both from within the region, and from observations in European studies.

The fauna is briefly discussed from a zoogeographic perspective; two species are Nearctic in origin, five may be Holarctic in distribution, and three others may be adventive Palaearctic species, although further evidence is required to confirm such preliminary assessments. Similarly, because of the paucity of information on this genus, further fieldwork is required to fully discern the distribution of these species in Atlantic Canada. Three are apparently saproxylic species characteristic of forested habitats; three are primarily grassland species; and the remaining four are eurytopic species found in a wide variety of forested and open habitats.
\end{abstract}

Copyright C.G. Majka, C. Johnson, D.W. Langor. This is an open access article distributed under the terms of the Creative Commons Attribution License, which permits unrestricted use, distribution, and reproduction in any medium, provided the original author and source are credited. 


\section{Keywords}

Cryptophagidae, Atomariinae, Atomaria, Atlantic Canada, New Brunswick, Newfoundland and Labrador, Nova Scotia, Prince Edward Island, biodiversity, zoogeography, bionomics, taxonomy, synonymy

\section{Introduction}

The genus Atomaria Stephens is the nominate genus of the Atomariinae, a subfamily of the family Cryptophagidae, the silken fungus beetles. They are small $(1.0-2.0 \mathrm{~mm})$, somewhat shiny, oval-oblong, pubescent beetles, typically found in leaf litter, grass litter, decaying vegetation, and in habitats which promote mycelial fungal growth on which adults and larvae feed (Leschen and Skelley 2002).

Members of this genus are divided into two subgenera, Atomaria s. str. and Anchicera Thomson. Bousquet (1991) reported 12 species in the subgenus Anchicera and 10 in Atomaria s. str. in Canada, although none were recorded as occurring in Atlantic Canada. Poole and Gentili (1996) listed 30 species in Anchicera and 41 in Atomaria s. str. from North America (although at least eight of these names have been synonymized) while Leschen and Skelley (2002) reported that there were 10 species in Atomaria sensu lato in North America (9 described; 1 undescribed). This confusion, and disparity in the numbers of species, is one indication that the genus is in need of extensive revision, the last comprehensive North American treatment being by Casey (1900).

In the Palaearctic region, Atomaria is much better known and understood. Recent publications by Lohse (1967) and Johnson (1992) have provided a solid taxonomic foundation for the genus, and Johnson et al. (2007) provided a complete catalogue of the genus in the Palaearctic region.

The paucity of knowledge about this genus in North America has impeded the identification of specimens, and limited our understanding of the historical, zoogeographic, distributional, biological, and ecological dimensions of Atomaria. The present study is a contribution to the knowledge of this genus in North America.

\section{Methods and conventions}

Specimens of Atomaria originating from Atlantic Canada in a variety of collections were examined and identified. These collections yielded 725 specimens; 425 from Nova Scotia, 49 from New Brunswick, nine from Prince Edward Island, and 242 from Newfoundland and Labrador. Abbreviations (largely following Evenhuis 2009) of collections consulted and referred to in this study are:

AAFC Agriculture and Agri-Food Canada, St. John's, Newfoundland and Labrador, Canada 
ACNS Agriculture and Agri-Food Canada, Kentville, Nova Scotia, Canada

ACPE Agriculture and Agri-Food Canada, Charlottetown, Prince Edward Island, Canada

BMNH The Natural History Museum, London, United Kingdom

CBU Cape Breton University, Sydney, Nova Scotia, Canada

CFS Canadian Forest Service, Corner Brook, Newfoundland and Labrador, Canada

CGMC Christopher G. Majka collection, Halifax, Nova Scotia, Canada

DHWC David H. Webster collection, Kentville, Nova Scotia, Canada

JCC Joyce Cook collection (now at the New Brunswick Museum, Saint John, New Brunswick, Canada)

JOC Jeffrey Ogden collection, Truro, Nova Scotia, Canada

KIC Kent Island Collection, Brunswick, Maine, United States

MMUE Manchester Museum, The University, Manchester, United Kingdom

MUN Memorial University of Newfoundland collection, St. John's, Newfoundland and Labrador, Canada (currently on long term loan to the Canadian Forest Service, Edmonton, Alberta, Canada)

MZHF Zoological Museum, University of Helsinki, Helsinki, Finland

NSMC Nova Scotia Museum, Halifax, Nova Scotia, Canada

NSNR Nova Scotia Department of Natural Resources, Shubenacadie, Nova Scotia, Canada

RWC Reginald Webster collection, Charters Settlement, New Brunswick, Canada

SMU Saint Mary's University, Halifax, Nova Scotia, Canada

UMNB Université de Moncton, Moncton, New Brunswick, Canada

In the species treatments, the number of specimens and the collection abbreviation are indicated in parentheses. Abbreviations employed are: FIT, flight intercept trap; uv, ultra violet; L., body length.

\section{Identification}

\section{Key to Atlantic Provinces species of Atomaria}

1. Antennae close basally, separated from each other by a distance not greater than their distance from eyes; antennomere 1 much longer than 2, obconnical; habitus elongate, parallel; width/length ratio $<0.35$ - Atomaria s. str. Stephens

- $\quad$ Antennae less close basally, more distant from each other than their distance from eye; antennomere 1 slightly longer than 2; habitus oval, short, compact; width/length ratio $>0.40$ - Anchicera Thomson.................................. 2

2(1). Elytra distinctly bicoloured (Figs 3, 4) ................................................ 3

- $\quad$ Elytral colouration variable, either unicoloured, or gradually paler apically, but not with a distinct bicoloured pattern ....................................... 4 


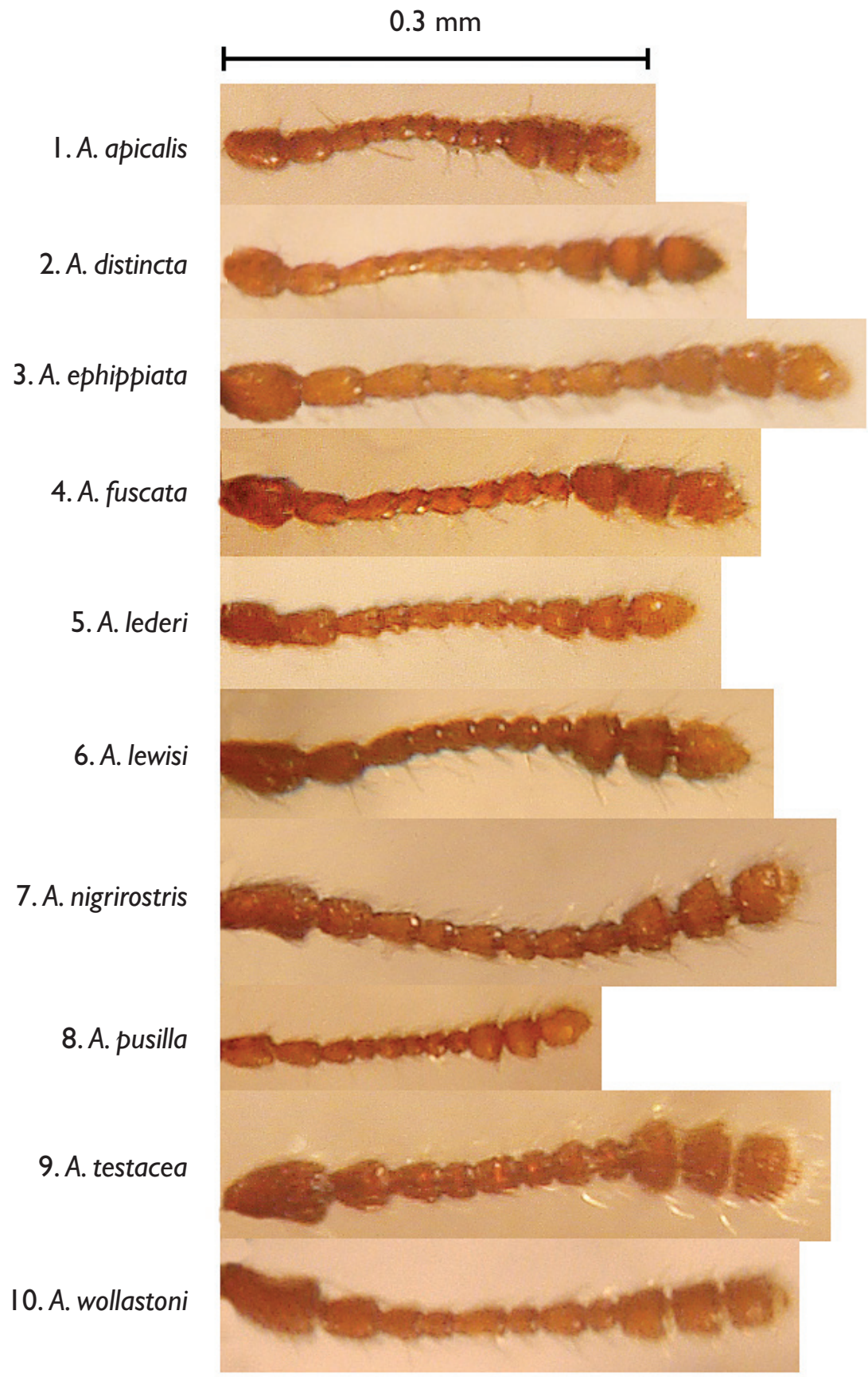

Figure I. Photographs of antennae of Atomaria species. I.I Atomaria apicalis I.2 Atomaria distincta I.3 Atomaria ephippiata I.4 Atomaria fuscata I.5 Atomaria lederi I.6 Atomaria lewisi I.7 Atomaria pusilla I.8 Atomaria testacea $\mathbf{1 . 9}$ Atomaria nigrirostris $\mathbf{I} . \mathbf{1 0}$ Atomaria wollastoni 
3(2) Elytra testaceous with a prominent piceous crossbar at the mid-point, either interrupted or continuous across suture; pronotum and prosternum piceous (Fig. 4). L. 1.5-1.6 mm Atomaria ephippiata Zimmerman

- $\quad$ Elytra abruptly ferruginous in apical $1 / 2$ to $2 / 5$ (Fig. 3); pronotum and prosternum (except near coxae) ferruginous. L. 1.4-1.5 mm

Atomaria distincta Casey

4(2) Lateral margin of pronotum evenly arcuate, broadest at point near middle; evenly narrowing to base; pronotal base straight or weakly curved; hind angles obtuse

- $\quad$ Lateral margin of pronotum in basal half more or less straight, not evenly arcuate; pronotal base sinuate or slightly bi-lobed; hind angles more rightangled

6

5(4). Antennomere 1 widening apically, at least 1.5 times as long as width of the antennomere at the apical end; clearly longer than antennomere 2 (Fig. 1.9). Habitus narrower, body width (at maximum width of elytra) to length ratio 0.47 ; pronotum comparatively shorter, pronotum to elytra ratio 0.46 . Elytra clearly gradually paler in apical half (Fig. 9). L. 1.3-1.6 mm

Atomaria testacea Stephens

- $\quad$ Antennomere 1 not noticeably wider apically; at most 1.3 times as long as width of the antennomere at the apical end; not or a slightly longer than antennomere 2 (Fig. 1.1). Habitus broader, body width to length ratio 0.54; pronotum comparatively longer, pronotum to elytra ratio 0.64 . Elytra indistinctly gradually paler in apical half (Fig. 2). L. $1.3-1.6 \mathrm{~mm}$

Atomaria apicalis Erichson

6(4). Testaceous to ferruginous in colour; antennal club distinct; antennomeres 9 and 10 slightly transverse to transverse ................................................... 7 Usually dark castaneous throughout, sometimes pronotum darker (Fig. 5); antennal club less distinct; antennomeres 9 and 10 frequently quadrate (Fig. 1.4). L. $1.4-1.7 \mathrm{~mm}$ Atomaria fuscata Schönherr

7(6) Antennomere 1 long, curved, 1.5-2.0 times as long as width of the antennomere at the apical end; much longer than antennomere 2 (Fig. 1.6). Lateral elytral margins evenly arcuate from widest point at middle. Body and elytra broad; width/length ratio of elytra 0.82 , width/length ratio of body 0.53 . Elytral setae somewhat erect and "bristling" (Fig. 7). L. 1.3-1.6 mm .

Atomaria lewisi Reitter

Antennomere 1 short, straight, not expanded at apex, hardly longer than wide, approximately as long as antennomere 2 (Figs 1.5, 1.8). Lateral elytral margins almost parallel in basal 3/4, narrowed to apex. Body and elytra narrower; width/length ratio of elytra 0.72 , width/length ratio of body 0.50 0.48 . Elytral setae short and appressed

8(7) Antennomere 2 slender, noticeably narrower than antennomere 1 (Fig. 1.7). Body dorso-ventrally flattened, depth/length ratio (in lateral view) 0.36 .1 .2 $\mathrm{mm}$ or less in length (Fig. 8). L. 1.0-1.2 mm....Atomaria pusilla (Paykull) 
- $\quad$ Antennomere 2 robust, at apex the same width (or almost so) as antennomere 1 at apex (Fig 1.5). Body dorso-ventrally deeper and more robust, depth/ length ratio (in lateral view) $0.43 .1 .2 \mathrm{~mm}$ or more in length (Fig. 6). L. 1.2-1.4 mm.................................................Atomaria lederi Johnson

9(1). Pronotal base with a strong transverse impression, laterally with several fine and sharp longitudinal ridges; pronotum widest at midpoint, lateral margins parallel to base, hind angles distinct (Fig. 10). L. 1.7-1.9 mm

Atomaria nigrirostris Stephens

- $\quad$ Pronotal base without a strong transverse impression and without sharp longitudinal ridges laterally; pronotum widest at midpoint, lateral margins evenly arcuate to base, hind angles rounded (Fig. 11). L. 1.5-1.8 mm .........

Atomaria wollastoni Sharp
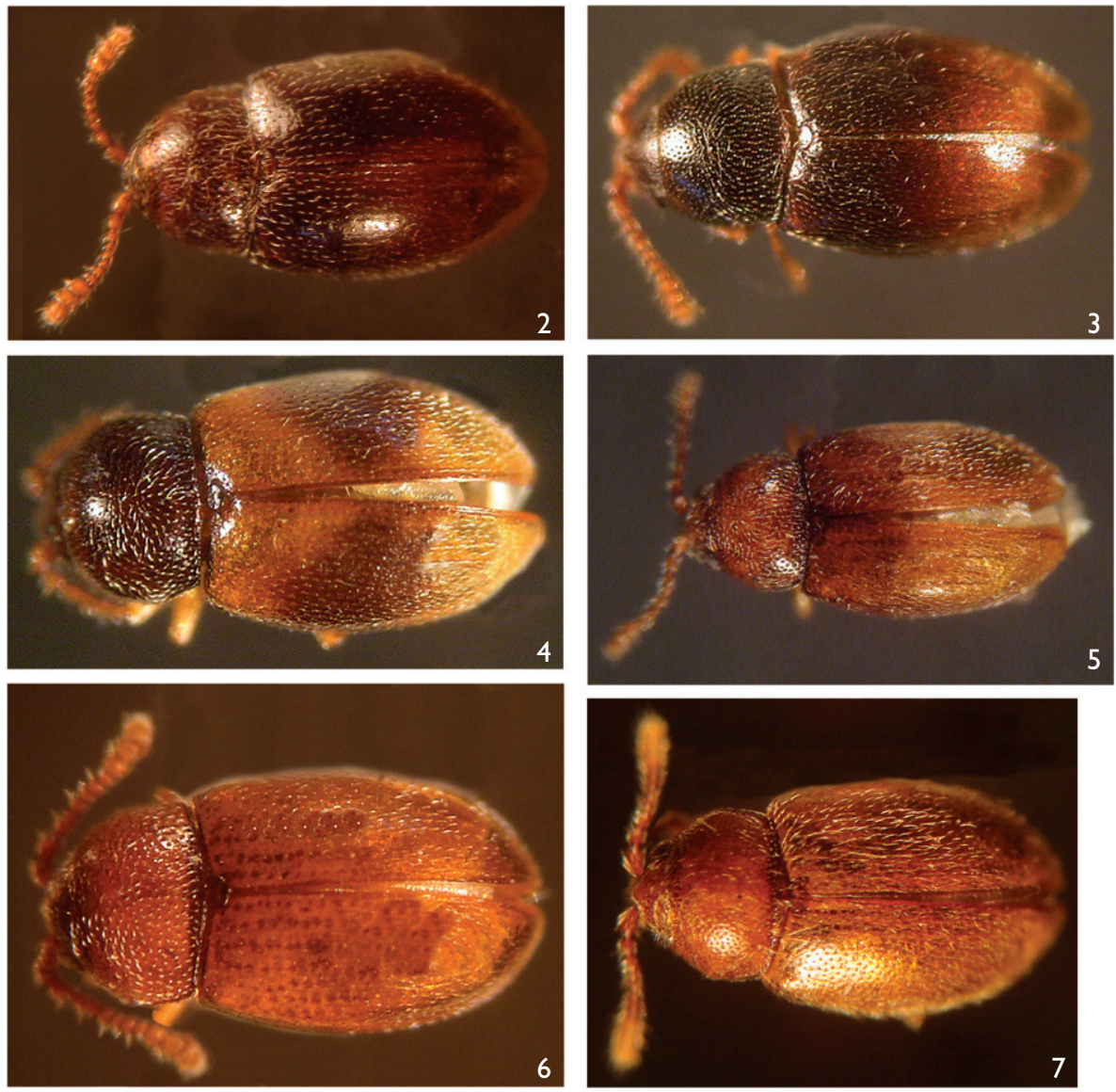

Figures 2-7. 2 Dorsal habitus photograph of Atomaria apicalis Erichson 3 Dorsal habitus photograph of Atomaria distincta Casey 4 Dorsal habitus photograph of Atomaria ephippiata Zimmerman 5 Dorsal habitus photograph of Atomaria fuscata Schönherr $\mathbf{6}$ Dorsal habitus photog raph of Atomaria lederi Johnson 7 Dorsal habitus photograph of Atomaria lewisi Reitter. 


\section{Results}

As a result of the present investigation, ten species of Atomaria have been recorded in Atlantic Canada; seven in New Brunswick, ten in Nova Scotia, one on Prince Edward Island, five on insular Newfoundland, and four in Labrador (Table 1), a total of 23 new provincial; records. Eight are in Atomaria s. str and two in Anchicera. Of these, six species including Atomaria distincta Casey, Atomaria fuscata Schönherr, Atomaria lederi Johnson, Atomaria lewisi Reitter, Atomaria testacea Stephens, and Atomaria nigrirostris Stephens are newly recorded in Canada. Atomaria lederi and A. lewisi are newly recorded in North America. Individual species accounts follow.

\section{Atomaria subgenus Anchicera Thomson, 1863}

\section{Atomaria apicalis Erichson, 1846}

NEWFOUNDLAND: Portugal Cove: Indian Meal Line, June 2, 1979, July 1, 1979, June 22, 1981, September 1, 1981, July 21, 1982 (14, MUN); Gander, July-August, 1998, D. Russell (2, MUN); South Pond near South Brook, June 27, 1980, Brennan \& Larson, drift (2, MUN). NEW BRUNSWICK: Albert Co.: Mary's Pt., September 8, 2002, C.G. Majka, old field, in compost (7, CGMC); Westmorland Co.:
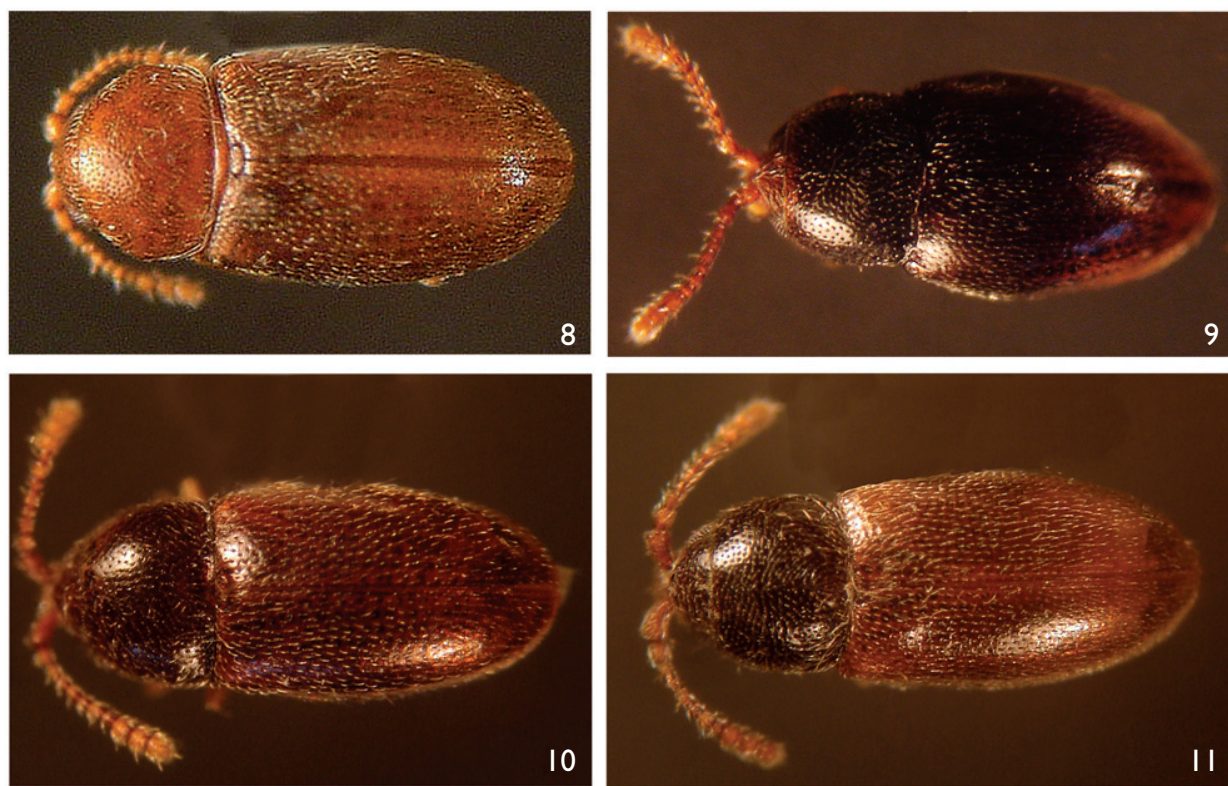

Figures 8-I I. 8 Dorsal habitus photograph of Atomaria pusilla (Paykull) 9 Dorsal habitus photograph of Atomaria testacea Stephens 10 Dorsal habitus photograph of Atomaria nigrirostris Stephens II Dorsal habitus photograph of Atomaria wollastoni Sharp. 

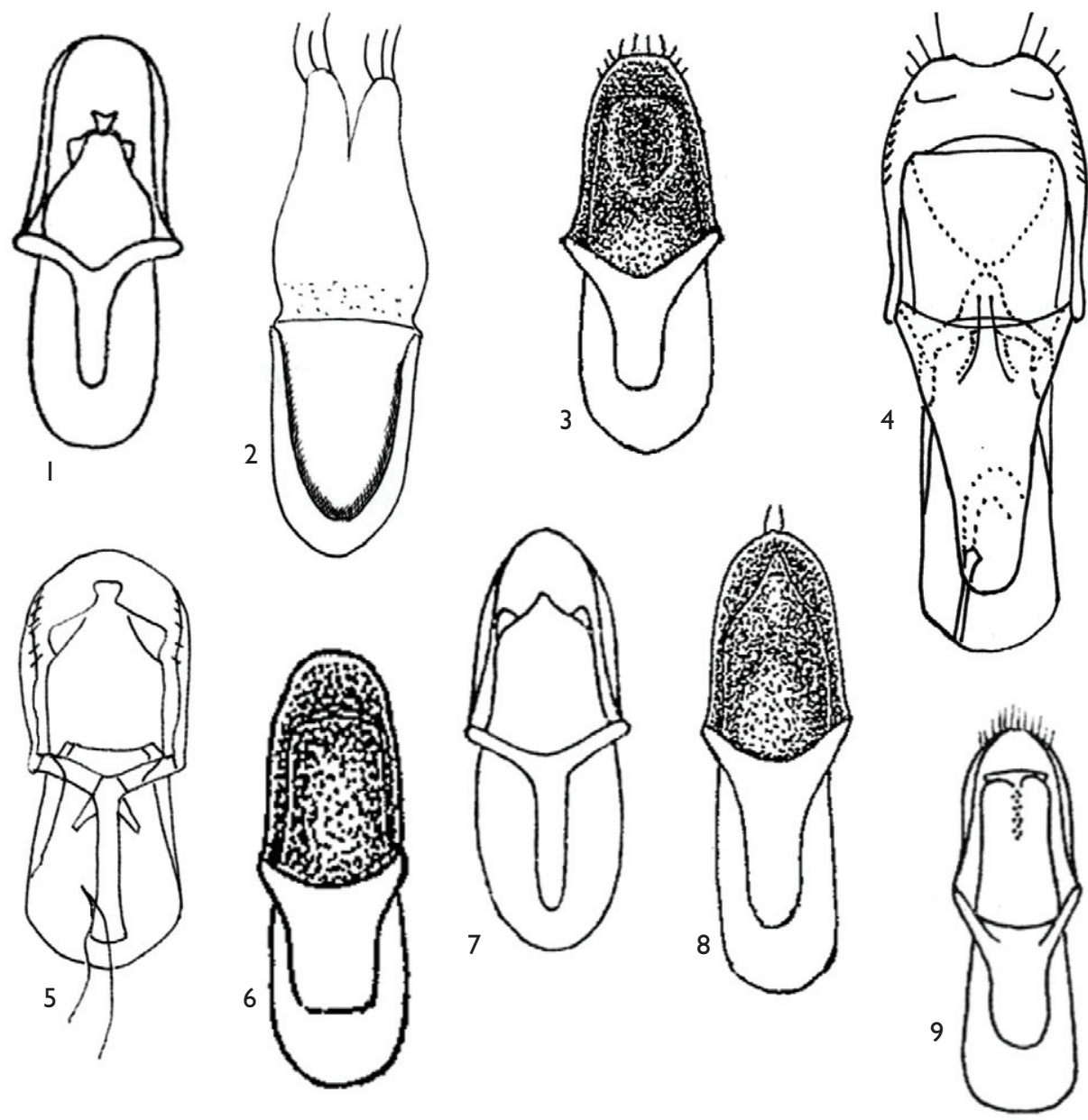

Figure 12. Adeagus illustrations of Atomaria species. I2.1 Atomaria apicalis 12.2 Atomaria ephippiata | 2.3 Atomaria fuscata I2.4 Atomaria lederi I 2.5 Atomaria lewisi 12.6 Atomaria pusilla I2.7 Atomaria testacea I 2.8 Atomaria nigrirostris I 2.9 Atomaria wollastoni. Adapted from Sjöberg (1947), Lohse (1967), Johnson $(1970,1971)$ with additional material. Note: no illustration of the adeagus of $A$. distincta was available.

Pointe-du-Chene, July 6, 1972, August 24, 1972,D.H. Murray (5, MMUE); NOVA SCOTIA: Halifax Co.: Halifax, September 7, 1972, D.H. Murray (2, MMUE); Halifax, July 1988, P.M. Hammond (1, BMNH); Lunenburg Co.: Bridgewater, June 30, 1965, B. Wright, red oak, window trap (1, NSMC); Queens Co.: Medway River, July 13, 1993, J. \& T. Cook, car net (2, JCC).

Atomaria apicalis is newly recorded in insular Newfoundland, New Brunswick, Nova Scotia, and Atlantic Canada (Fig. 16). We have examined the holotype of Atomaria ovalis Casey 1900 deposited in the Smithsonian Institution and have found it to 
Table I. Atomaria fauna of Atlantic Canada

\begin{tabular}{|c|c|c|c|c|c|c|}
\hline & NB & NS & PE & NF & LB & Origin \\
\hline \multicolumn{7}{|l|}{ Atomaria (Anchicera) Thomson } \\
\hline Atomaria apicalis Erichson & 1 & 1 & & 1 & & Holarctic \\
\hline Atomaria distincta Casey & 1 & 1 & & & & Nearctic \\
\hline Atomaria ephippiata Zimmerman & 1 & 1 & & 1 & 1 & Nearctic \\
\hline Atomaria fuscata Schönherr & 1 & 1 & 1 & 1 & 1 & Holarctic \\
\hline Atomaria lederi Johnson & & 1 & & & & Holarctic? \\
\hline Atomaria lewisi Reitter & 1 & 1 & & & & Palaearctic? \\
\hline Atomaria pusilla (Paykull) & 1 & 1 & & & & Palaearctic \\
\hline Atomaria testacea Stephens & 1 & 1 & & & & Palaearctic? \\
\hline \multicolumn{7}{|l|}{ Atomaria (s. str.) Stephens } \\
\hline Atomaria nigrirostris Stephens & & 1 & & 1 & 1 & Holarctic? \\
\hline Atomaria wollastoni Sharp & & 1 & & 1 & 1 & Holarctic? \\
\hline Total & 7 & 10 & 1 & 5 & 4 & \\
\hline
\end{tabular}

Notes: LB, Labrador; NB, New Brunswick; NF, insular Newfoundland; NS, Nova Scotia; PE, Prince Edward Island.

be identical in all respects to $A$. apicalis Erichson. We therefore designate $A$. ovalis syn. n. as a junior synonym of $A$. apicalis.

In North America this species has previously been reported from Connecticut, Indiana, Iowa, Maine, Manitoba, Massachusetts, New Hampshire, New York, Québec (Blatchley 1910; Britton 1920; Leng 1920; Procter 1946; Bousquet 1991; Downie and Arnett 1996; Chandler 2001). It is widely distributed in the Palaearctic region being found throughout Europe and North Africa, east across Siberia to the Russian Far East, across the Middle East, to Central Asia, Mongolia, and Fujian in China (Johnson et al. 2007). Johnson (1993) reported that it was, "a grassland species which has been recorded especially around farms, gardens and parks but often occurs in other habitats. It has been collected in man-made heaps of refuse, especially cut vegetation, grass, compost and dung heaps, flood debris, and more rarely on carrion and rotting fungi."

Description: A variable species; head, pronotum, and elytra piceous to castaneous or (more rarely) black; elytra sometimes paler in apical $2 / 5$. Legs, prosternum, and abdominal sterna reddish-testaceous. Pronotum weakly constricted from middle to base; from middle to apex even more strongly. Rarely, in males the basal half of the pronotum is parallel-sided, or very weakly constricted basally. Punctures of the pronotum and elytra very variable; on the base of the pronotum, interspaces between punctures -1.0 times the diameter of puctures. Punctation of elytra similar to that of pronotum, or finer and shallower, but always less dense. Distance between furrows of prosternal process approximately half the width of the prosternal process. Body strongly convex in cross-section (Fig. 2). Antennae: antennomere 1 swollen, slightly longer than 2; 3 as long as 2 but narrower; $4-8$ short and bead-like; club distinct, antennomeres 9 and 10 slightly transverse (Fig. 1.1). Body: width/length ratio, 0.41 ; length, $1.3-1.6 \mathrm{~mm}$. 


\section{Atomaria distincta Casey, 1900}

NEW BRUNSWICK: Westmorland Co.: Moncton, July 6, 1972, D.H. Murray (1, MMUE). NOVA SCOTIA: Halifax Co.: West Dover, September 7, 2003, C.G. Majka, salt marsh (4, CGMC).

Atomaria distincta is newly recorded in New Brunswick, Nova Scotia, and Canada (Fig. 14). This Nearctic species has previously been reported from the District of Columbia, Massachusetts, New York, and Québec (Leng 1920; Downie and Arnett 1996).

Description: Head piceous, finely sparsely punctate. Pronotum piceous, finely sparsely punctate; pronotum widest at or slightly ahead of midpoint, not appreciably flattened across base; finely sparsely punctate; interspaces between punctures 1.5-2.0 times the diameter of punctures. Scutellum black. Basal 3/5 of elytra black, becoming abruptly yellow in apical $2 / 5$, the yellow portion extending slightly anterad in the region of the suture. Punctation very fine and sparse; interspaces between punctures 2.0-3.0 times the diameter of punctures; elytral setae very fine and short, shorter than interspace intervals and appressed. Legs, prosternum, and abdominal sterna reddishtestacous; sterna darker basally and laterally (Fig. 3). Antennae: antenomere 1 short, almost quadrate, not longer than 2; 2 slightly shorter than 1 and slightly narrower; 3 as long as 2 and slightly more slender; 4, 5 and 7 slightly shorter than 3; 6 and 8 still shorter, each approximately $1 / 2$ the length of 3 , not bead-like; antennal club distinct, antennomeres 9 and 10 almost quadrate, not noticibly transverse (Fig. 1.2). Body: width/length ratio, 0.43 ; length, $1.4-1.5 \mathrm{~mm}$.

\section{Atomaria ephippiata Zimmerman, 1869}

LABRADOR: Otter Creek, Goose Bay, July 28-August 8, 2008, G.R. Pohl \& D.W. Langor, forb meadow, 15 m, pitfall (4, MUN). NEW BRUNSWICK: Sunbury Co.: Burton, May 25, 1972, D.H. Murray (3, MMUE); Westmorland Co.: Pointe-duChene, August 24, 1972, D.H. Murray (2, MMUE); Sackville, August 27, 1982, P. Maltais (1, CGMC); York Co.: New Maryland, June 26, 2003, R.P. Webster, mixed forest, at light (1, RWC); New Maryland, April 15, 2004, R.P. Webster, mixed forest, compost (1, RWC). NEWFOUNDLAND: Cinq Cerf River, June 16, 1949, E. Palmen (1, MZHF); Burnt Cape, August 7-21, 2003, A.M. Hynes, coastal meadow, pitfall (1, CFS); Glide Lake, June 13, 1996, July 11, 1996, July 25, 1996, pitfall, August 8, 1996 (4, CFS); Glide Lake, July-August, 1994, C. Bassler (1, MUN). NOVA SCOTIA: Annapolis Co.: Durland Lake, June 6, 2003, P. Dollin, hemlock/balsam fir/black spruce (120+ years), sweeping (1, NSMC); Colchester Co.: Bible Hill, June 15-24, 2005, May 31, 2005, K.R. Aikens, pasture, pitfall trap (4, CBU); Bible Hill, June 15, 2007 , June 19, 2007, July 8, 2007,C.W. D’Orsay, pasture, sweeping (6, CBU); Debert, July 13 1994, J. Ogden (1, NSNR); Cumberland Co.: Amherst, June 24, 1994, J. Ogden (1, NSNR); Oxford, July 31, 1988, August 11, 1988, E. Georgeson, uv light trap (2, 


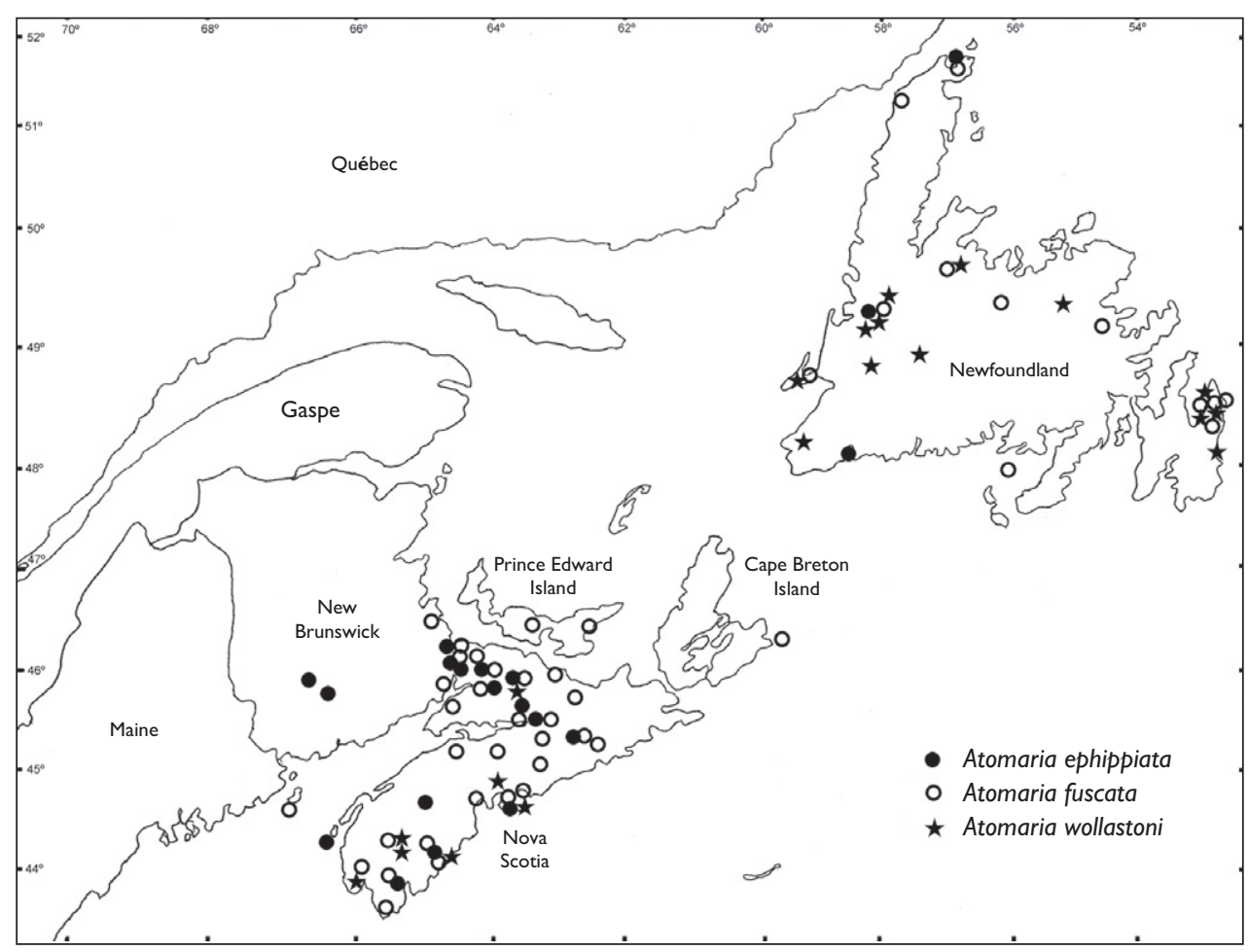

Figure 13. Distribution of Atomaria ephippiata, Atomaria fuscata, and Atomaria wollastoni in Atlantic Canada.

NSMC); Wentworth Park, July 12, 1993, J. \& T. Cook, car net (1, JCC); WestchesterLondonderry, August 22, 1992, S. \& J. Peck, forest road, car net (12, JCC); Digby Co.: Brier Island: Western Light, June 24, 2003, J. Ogden \& K. Goodwin, raised bog, pitfall trap (1, JOC); Guysborough Co.: Trafalgar, Liscomb Sanctuary, July 19, 1992, S. \& J. Peck, car net (3, JCC); Halifax Co.: West Dover, September 7, 2003, C.G. Majka, salt marsh (4, CGMC); Queens Co.: Medway River, July 13, 1993, J. \& T. Cook, car net (13, JCC); Shelburne Co.: Clyde River Rd, July 16, 1992, S. \& J. Peck, forest, car net (1, JCC).

Atomaria ephippiata is newly recorded in Labrador, New Brunswick, insular Newfoundland, and Nova Scotia (Figs 13, 17). This Nearctic species has previously been recorded in Alberta, British Columbia, Colorado, Connecticut, Idaho, Indiana, Iowa, Maine, Manitoba, Massachusetts, New Hampshire, New York, Ontario, Oregon, Québec, Rhode Island, Washington, and Wisconsin (Blatchley 1910; Britton 1920; Leng 1920; Procter 1946; Hatch 1961; Oatman et al. 1964; Bousquet 1991; Downie and Arnett 1996; Schwert 1996; Chandler 2001; Jacobs et al. 2006; Sikes 2004). It has been reported on fungi and molds in litter and nests (LaBonte 1998). In Atlantic Canada it has been found in mixed forests, coniferous forests, along forest roads, in raised bogs, salt marshes, and pastures. Jacobs et al. (2006) and Hammond et al. (2001) both reported this species as a member of saproxylic beetle assemblages on Populus tremuloides Michx (Salicaceae) in Alberta. 
Description: Head piceous; finely sparsely punctate. Pronotum piceous; distinctly widest at midpoint, narrowing to base and apex; flattened across basal margin; finely sparsely punctate, interspaces between punctures -2.0 times the diameter of punctures. Scutellum piceous. Elytra testaceus, slightly darker along suture, with a pominent piceous crossbar at approximately the $2 / 5$ point of the elytra, slightly curved posterad and frequently extending across the suture; punctures slightly coarser and slightly denser than on pronotum; interspaces between punctures $\sim 1.5$ times the diameter of puctures; elytral setae slightly longer than interspace distance and appressed (Fig. 4). Antennae: antenomere 1 swollen, wider and longer than 2; 3 almost the same length as 2; 4, 6, and 8 short and of similar length; 5 and 7 somewhat longer; antennal club somehwat indistinct and not clearly demarcated, antennomere 9 only slightly wider than 8; 9 and 10 quadrate, not transverse (Fig. 1.3). Body: width/length ratio, 0.46; length, $1.5-1.6 \mathrm{~mm}$.

\section{Atomaria fuscata Schönherr, 1808}

LABRADOR: Happy Valley, near Churchill River, July 29, 2008, G.R. Pohl \& D.W. Langor, at dusk, 15 m (1, MUN). NEW BRUNSWICK: Albert Co.: Mary's Pt., August 23, 2003, August 12, 2004, C.G. Majka, ocean beach, in beach drift (4, CGMC); Charlotte Co.: Kent Island, Grand Manan archipelago, June 25, 2008, M. Steck, west beach (1, KIC); Kent Co.: Bouctouche, May 25, 2007, J.-P. Michaud, on decaying pig (1, UMNB); Westmorland Co.: Pointe-du-Chene, July 6, 1972, June-July, 1972, D.H. Murray (6, MMUE); Sackville, August 27, 1982, P. Maltais (1, CGMC). NEWFOUNDLAND: St. Barbe, July 26, 1949, E. Palmen (1, MZHF); Piccadilly, July 7, 1949, E. Palmen (1, MZHF); Glide Lake, August 30, 1994, pitfall (1, MUN); Goulds, May 22, 1953, May 29, 1953, June 3, 1953, June 4, 1953, June 5, 1953, June 6, 1953 , June 9, 1953, June 10, 1953, June 11, 1953, June 19, 1953 (52, AAFC); Goulds, June 9, 1953, R.F. Morris (1, AAFC); Kilbride, St. John's, June 6, 1982, R.F. Morris (1, AAFC); Mount Pearl, November 10, 1995, Dave McKenzie (1, AAFC); Portugal Cove: Indian Meal Line, June 13, 1978, D. Larson (1, MUN); Portugal Cove: Indian Meal Line, May 16, 1979, May 21, 1979, July 1, 1979, July 31, 1982 (19, MUN); Portugal Cove: Indian Meal Line, July 1, 1979 (4, CFS); St John's, July 12, 1974, July 16, 1974, R.F. Morris (2, AAFC); St John's, October 18, 1977, D. Larson (1, MUN); St John's, September, 1988, Biology 4150 (6, MUN); St John's, Long Pond, May 29, 1981 (1, MUN); Bishop's Falls, August 17, 1979, E. John (1, AAFC); South Pond near South Brook, June 27, 1980, Brennan \& Larson, drift (1, MUN); Millville, Grandaddys Brook, June 16, 1979, Larson \& Swales (1, MUN); 1 mi. east of Traytown, July 27, 1970, D.E. Bright (4, MUN); Burnt Cape, July 10-24, 2003, August 7-21, 2003, August 21-September 4, 2003, A.M. Hynes, shoreline, pitfall (8, MUN); Burnt Cape, July 10-24, 2003, July 24-August 7, 2003, A.M. Hynes, coastal meadow, pitfall (8, MUN); Burnt Cape, July 24-August 7, 2003, A.M. Hynes, cow parsnip patch, pitfall (7, MUN); Brunette Island, June 26-30, 1995, A.G. Raske, dense vegetation, pitfall 
(2, MUN). NOVA SCOTIA: Cape Breton Co.: Scatarie Island: E. Harbour, July 15, 2006, A. MacDonald, freshwater pond (2, CBU); Scatarie Island: NW Cove, August 8, 2005, A. MacDonald, beach, under wrack (1, CBU); Colchester Co.: 4 km N of Brookfield, June 23, 1995, J. Cook, mixed forest, uv light trap (1, JCC); Bible Hill, May 31, 2005, June 15-24, 2005, K.R. Aikens, pasture (3, CBU); Bible Hill, May 31, 2005, June 30, 2005, July 21, 2005, S.M. Townsend, pasture, sweeping (12, CBU); Bible Hill, May 27, 2004, D.B. McCorquodale, pasture, sweeping (1, CBU); Bible Hill, May 31, 2007, C.W. D’Orsay, pasture, sweeping (2, CBU); Masstown, June 7, 1990, T.D. Smith (1, NSNR); Cumberland Co.: Chignecto Game Sanctuary, July 30, 1988, E. Georgeson, uv light trap (1, NSMC); Oxford, August 16, 1986, August 12, 1988,E. Georgeson, uv light trap (4, NSMC); Wentworth Park, July 12, 1993, J. \& T. Cook, car net (5, JCC); Westchester-Londonderry, July 20, 1992, S. \& J. Peck, forest road, car net (12, JCC); Guysborough Co.: Malay Lake, 2-15 June, 1997, D.J. Bishop, red spruce, FIT (1, NSMC); Trafalgar, Liscomb Sanctuary, July 19, 1992, S. \& J. Peck, car net (25, JCC); Halifax Co.: Middle Musquodoboit, September 3, 1988, E. Georgeson, uv light trap (1, NSMC); Halifax, July, 1988, P.M. Hammond, 5 specimens brachypterous (8, BMNH); Pt. Pleasant Park, July 5, 1990, S. Robertson, coniferous forest, stovepipe trap (1, NSMC); West Dover, September 7, 2003, C.G. Majka, salt marsh (3, CGMC); Hants Co.: Upper Rawdon, June 25, 2008, J. Renkema, highbush blueberry field, pitfall trap (4, CGMC); Kings Co.: Kentville, August 19, 2007, D.H. Webster, compost, moldy corncobs (1, DHWC); Lunenburg Co.: Chester, June 22, 1960, B. Wright (1, NSMC); Pictou Co.: McLellan's Brook, August 5, 1988, E. Georgeson, uv light trap (1, NSMC); Seafoam, August 11, 2008, C.G. Majka, seashore, beach drift (1, CGMC); Queens Co.: Medway River, July 13, 1993, J. \& T. Cook, car net (5, JCC); Ponhook Lake nr. Greenfield, July 13, 1993, J. Cook, uv light trap (1, JCC); Kejimkujik National Park, September 26-19 October, 1994, B. Wright, hemlock stand (1, NSMC); Shelburne Co.: Clyde River Rd, July 16, 1992, S. \& J. Peck, forest, car net (3, JCC); Sebim Beach, July 19, 1993, J. \& T. Cook (1, JCC); Yarmouth Co.: Carleton: Perry Rd., August 22, 1992, J. \& F. Cook, mixed forest, car net (2, JCC); Carleton: Perry Rd., July 18, 1993, J. \& T. Cook, car net (3, JCC). PRINCE EDWARD ISLAND: Queens Co.: Harrington, June 14, 2004, C. Noronha, barley field, pitfall trap (1, ACPE); Harrington, June 1, 1987, L.S. Thompson, potato field (3, ACPE); Harrington, September 8, 2005, M.E.M. Smith, barley $\&$ hedgerows, sweep (1, CGMC).

We have examined the holotype of Atomaria saginata Casey 1900 deposited in the Smithsonian Institution and have found it to be identical in all respects to $A$. fuscata Schönherr. We therefore designate $A$. saginata (syn. n.) as a junior synonym of $A$. fuscata.

Atomaria fuscata is newly recorded in Labrador, New Brunswick, insular Newfoundland, Nova Scotia, and Prince Edward Island (Figs 13, 17). Johnson et al. (2007) designated Atomaria ochracea Zimmerman, 1869 as a junior synonym of A. fuscata, and Atomaria lacustris Casey, 1900 and Atomaria pennsylvanica Casey, 1900 had previously been designated as junior synonyms of $A$. ochracea (by Leng 1920). Majka and Shaffer's (2008) discussion of $A$. ochracea is attributable to A. fuscata. 
This species has been recorded in British Columbia, the District of Columbia, Idaho, Indiana, Maine, Manitoba, Maryland, Michigan, New Hampshire, New York, Ontario, Oregon, Pennsylvania, Rhode Island, Québec, Virginia, Washington, and Wisconsin (LeConte 1869; Blatchley 1910; Leng 1920; Procter 1946; Hatch 1961; Oatman et al. 1964; Bousquet 1991; Downie and Arnett 1996; Chandler 2001; Sikes 2004). In the Palaearctic region it is known throughout Europe, across Siberia to the Russian Far East, south to Tibet and northern China, and in the Middle East in Turkey and Israel (Johnson et al. 2007). Hatch (1961) reported it as very common on herbiage and in grass clippings, compost, leaf litter, and humus. In Atlantic Canada it has been collected in mixed and coniferous forests, pastures, blueberry and potato fields, hedgerows, in coastal dunes and on ocean beaches under drift, by freshwater ponds, and in compost. Johnson (1993) reported that it, "occurs in a range of habitats - grassland, wetland, and woodland - especially in damp situations, and has been collected in litter, moss, flood refuse, cut vegetation and compost heaps."

Description: Dorsum and venter usually dark red-brown castaneous, pronotum occasionally darker than elytra. Legs reddish-testaceous. Pronotal punctures moderately fine and dense apically, becoming progressively coarser and denser basally; pronotum widest at middle, strongly narrowing basally and apically; base with a distinct transverse impression, the middle third of the basal margin with a discernable, fine marginal bead. Elytral punctures very fine and sparse; interspaces between punctures $3.0+$ times the diameter of punctures. Setae the length of the interspaces, appressed (Fig. 5). Antennae: antennomere 1 swollen, longer and wider than 2; 3 as long as or longer than 2 but more slender; 4-8 small and somewhat bead-like; antennal club distinct; antennomeres 9 and 10 quadrate, not discernibly transverse (Fig. 1.4). Body: width/length ratio, 0.47 ; length, $1.4-1.7 \mathrm{~mm}$.

\section{Atomaria lederi Johnson, 1970}

NOVA SCOTIA: Colchester Co.: Five Islands Park, September 6, 1988, E. Georgeson, uv light trap (2, NSMC); Cumberland Co.: Oxford, August 11, 1988, E. Georgeson, uv light trap (1, NSMC); Guysborough Co.: Dayspring Lake, 2-15 June, 1997, 1-16 July, 1997, D.J. Bishop, red spruce, FIT (2, NSMC); George Lake, 14 May-2 June, 1997, D.J. Bishop, red spruce (young), FIT (1, NSMC); Malay Lake, 14 May-2 June, 1997, 15-30 June, 1997, 1-16 July, 1997, D.J. Bishop, red spruce, FIT (8, NSMC); Melopseketch Lake, 1-16 July, 1997, D.J. Bishop, red spruce (young), FIT (1, NSMC); Seloam Lake, 14 May-2 June, 1997, 2-15 June, 1997, 15-30 June, 1997, D.J. Bishop, red spruce, FIT (3, NSMC); Halifax Co.: Big St. Margarets Bay, 2-15 June, 1997, 29 July-13 August, 1997, D.J. Bishop, red spruce, FIT (2, NSMC); Grassy Lake, 15-30 June, 1997, 1-16 July, 1997, D.J. Bishop, red spruce, FIT (4, NSMC); Moser Lake, 15-30 June, 1997, 1-16 July, 1997, D.J. Bishop, red spruce, FIT (2, NSMC); Pockwock Lake, 29 July-13 August, 1997, D.J. Bishop, red spruce (mature), FIT (1, NSMC); Porters Lake, September 2, 1993, B. Wright (2, NSMC); 


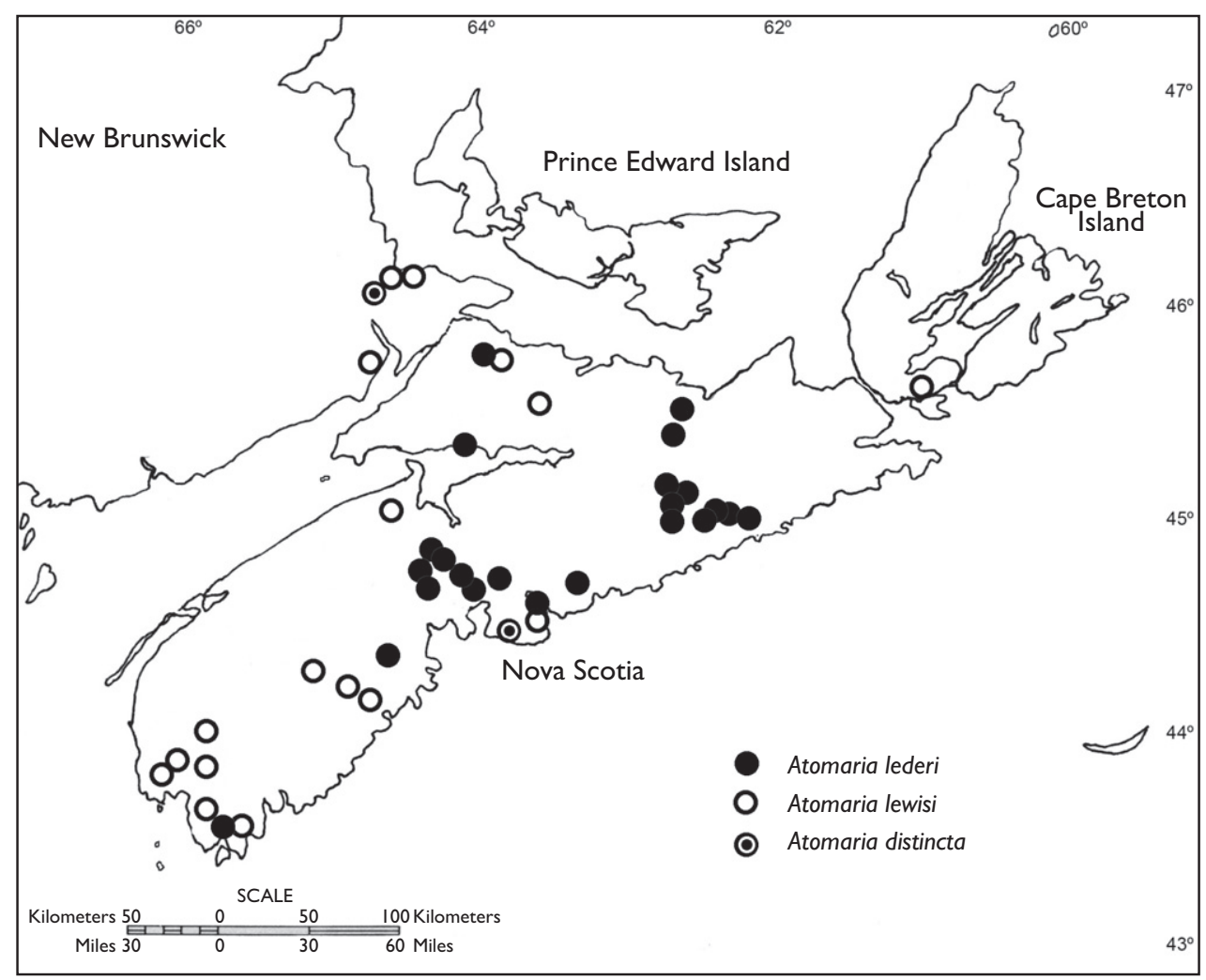

Figure 14. Distribution of Atomaria lederi, Atomaria lewisi, and Atomaria distincta in Atlantic Canada.

Pt. Pleasant Park, June 7, 2001, June 27, 2001, July 7, 2001, May 9, 2002, C.G. Majka, boggy area, (5, CGMC); Sandy Lake, 2-15 June, 1997, 29 July-13 August, 1997, D.J. Bishop, red spruce (120+ years), FIT (2, NSMC); Ten Mile Lake, 15-30 June, 1997, D.J. Bishop, red spruce, FIT (1, NSMC); Hants Co.: Armstrong Lake, 14 May-2 June, 1997, D.J. Bishop, red spruce (75 years), FIT (2, NSMC); Leminister, 15-30 June, 1997, D.J. Bishop, red spruce/eastern hemlock, FIT (1, NSMC); Little Armstrong Lake, 14 May-2 June, 1997, D.J. Bishop, red spruce (75 years), FIT (1, NSMC); Lunenburg Co.: Bridgewater, May 27, 1965, B. Wright, red oak, window trap (1, NSMC); Card Lake, 15-30 June, 1997, D.J. Bishop, red spruce/eastern hemlock (old), FIT (1, NSMC); Pictou Co.: Lorne, 15-30 June, 1997, D.J. Bishop, red spruce/ eastern hemlock (mature), FIT (1, NSMC); McLellan's Brook, July 29, 1988, E. Georgeson, uv light trap (1, NSMC); Shelburne Co.: Barrington, May 18, 1966, collector not noted, attic of old meeting house (1, NSMC).

Atomaria lederi is newly recorded in North America (Fig. 14). The reference to North America in Johnson et al. (2007) refers to some of the above records. In the Palaearctic region this species has been recorded from central and northern Russia, east across Siberia to the Russian Far East, and south to Mongolia, North Korea, and northern China (Liaoning) (Johnson et al. 2007). In Nova Scotia it has primarily 
been found in mixed red spruce (Picea rubens Sarg.) and eastern hemlock (Tsuga canadensis (L.) Carr.) (Pinaceae) forests of various ages, occasionally in boggy areas in such forests, on Spiraea alba Duroi (Rosaceae), and balsam fir (Abies balsamea (L.) Mill) (Pinaceae).

Description: Dorsum and venter reddish-testaceous throughout, including legs. Head, pronotum, and elytra moderately coarsely, moderately densely punctate; interspaces 1.0-1.5 times the diameter of punctures; elytral setae the length of the interspaces, appressed. Pronotum widest at middle, narrowing slightly to base and more strongly to apex (Fig. 6). Antennae: antennomere 1 quadrate, swollen; 2 the same length and almost the same width as 1; 3 slightly shorter and narrower; 4-8 similar in size and bead-like; club distinct; antennomeres 9 and 10 quadrate, not transverse (Fig. 1.5). Body: width/length ratio, 0.43; length, 1.2-1.4 mm.

\section{Atomaria lewisi Reitter, 1877}

NEW BRUNSWICK: Albert Co.: Mary's Pt., September 8, 2002, C.G. Majka, old field, in compost (3, CGMC); NOVA SCOTIA: Cumberland Co.: Oxford, June 16, 1986, E. Georgeson (1, NSNR); Wentworth Park, July 12, 1993, J. \& T. Cook, car net (5, JCC); Halifax: Pt. Pleasant Park, August 10, 2001, August 18, 2001, C.G. Majka, coniferous forest, boggy area, Spiraea alba (3, CGMC); Kings Co.: Kentville, August 10, 2005, D.H. Webster, compost, moldy corncobs (5, DHWC); Queens Co.: Caledonia, July 25, 1992, J. \& F. Cook, interior mixed forest, car net (4, JCC); Medway River, July 13, 1993, J. \& T. Cook, car net (1, JCC); Ponhook Lake nr. Greenfield, July 13, 1993, J. Cook, uv light trap (1, JCC); Richmond Co.: Louisdale, November 12, 1991, M. Boudreau (4, NSMC); Shelburne Co.: Clyde River Rd, July 16, 1992, S. \& J. Peck, forest, car net (1, JCC); Yarmouth Co.: Carleton, Perry Rd., August 22, 1992, J. \& F. Cook, mixed forest, car net (7, JCC); Carleton, Perry Rd., July 18, 1993, J. \& T. Cook, car net (3, JCC); Coldstream Rd. E of Quinan, July 19, 1993, J. \& T. Cook, car net (1, JCC); Hebron, June 4, 1999, J. Cook, on Hawthorne (1, JCC); north of North Kemptville, August 23, 1992, J. \& F. Cook, car net (6, JCC); Wellington, July 11-12, 1997, J. Cook, uv light trap (3, JCC); Yarmouth-Shelburne Co.: Oak Park Rd., August 27, 1992, J. \& F. Cook, car net (9, JCC).

We have examined the holotype of Atomaria curtula Casey 1900 deposited in the Smithsonian Institution and have found it to be identical in all respects to $A$. lewisi Reitter. We therefore designate $A$. curtula syn. n. as a junior synonym of $A$. lewisi.

Atomaria lewisi is newly reported in New Brunswick, Nova Scotia, Canada, and North America (Fig. 14). Under the name A. curtula it was reported from Connecticut, Ontario (Casey 1900; Leng 1920; Bousquet 1991; Downie and Arnett 1996), and Maine (Procter 1946). In the Palaearctic region it is found throughout Europe, the Russian Far East, Central Asia, Mongolia, China, Japan, and North Korea, south to Bhutan and northern India (Johnson et al. 2007). 
Lohse (1967) called it an adventive species in Europe, and Johnson et al. (2007) referred to it as cosmopolitan. In Nova Scotia it has been found in coniferous and mixed forests, in boggy areas, on Craetegus sp. (Rosaceae), and on compost. Johnson (1993) reported that it was, "a grassland species which has been recorded especially around farms, gardens and parks but it often also occurs in other habitats. It has been collected in man-made heaps of refuse, especially cut vegetation, hay, grass, and compost."

Description: Dorsum and venter brownish-yellow or reddish-yellow throughout, including legs. Head moderately densely, moderately finely punctate. Pronotum moderately densely and moderately coarsely punctate; interspaces 0.5 times the diameter of punctures; base with a distinct flattened depression. Elytra somewhat more finely and sparsely punctate; interspaces 1.0-1.5 times the diameter of punctures; elytral margins strongly rounded; setae rather long and prominently erect giving a "bristling" appearance (Fig. 7). Antennae: antennomere 1 long, swollen, and curved, apex nearly 1.5-2.0 times the width of base, 1.5 times longer than $2 ; 3$ the same length as 2 but more slender; $4-8$ almost equal in length and bead-like; club distinct; antennomeres 9 and 10 slightly transverse (Fig. 1.6). Body: width/length ratio, 0.46; length, $1.3-1.6 \mathrm{~mm}$.

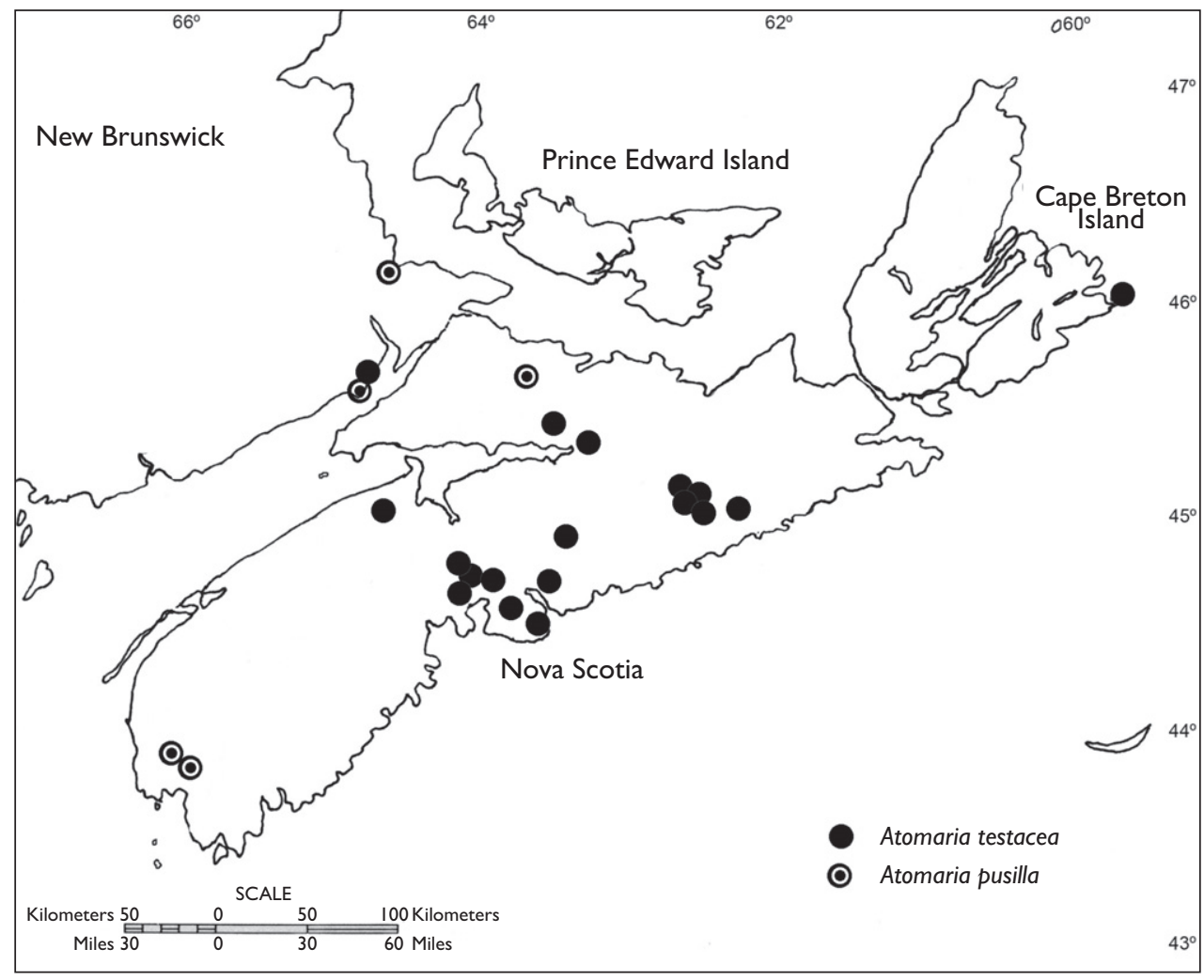

Figure 15. Distribution of Atomaria testacea and Atomaria pusilla in Atlantic Canada. 
Atomaria pusilla (Paykull, 1798)

NOVA SCOTIA: Cumberland Co.: Wentworth Park, July 12, 1993, J. \& T. Cook, car net (2, JCC); Yarmouth Co.: Carleton: Perry Rd., July 18, 1993, J. \& T. Cook, car net (1, JCC); Coldstream Rd. E of Quinan, July 19, 1993, J. \& T. Cook, car net (2, JCC). NEW BRUNSWICK: Albert Co.: Mary’s Pt., August 9, 2002, C.G. Majka, coniferous forest, decaying Russula virescens (1, CGMC); Westmorland Co.: Shediac, September 30, 1972 (1, MMUE).

Atomaria pusilla is newly recorded in New Brunswick and Nova Scotia (Fig. 15). In North America it has been recorded in Alaska, British Columbia, Connecticut, Idaho, Indiana, New York, Ohio, Oregon, Québec, and Washington (Blatchley 1910; Britton 1920; Notman 1920; Hatch 1961; Bousquet 1991; Williams et al. 1995; Downie and Arnett 1996). Blatchley (1910) referred to it as a "European" species and Bousquet (1991) listed it as "probably introduced" in North America. In the Palaearctic region it is found throughout Europe (including Turkey), across North Africa, and in central Asia in Iran, Afghanistan, and Kazhakhstan, northeast to Mongolia and the Russian Far East (Johnson et al. 2007). Blatchley (1910) reported it from the borders of a sphagnum marsh and in other damp vegetable debris. In New Brunswick it was found in a coniferous forest on a decaying gill fungus. Johnson (1993) reported that it was, "a grassland species which is found especially around farms and gardens and only rarely elsewhere, It has been collected in man-made heaps of refuse, cut vegetation, hay, grass, and compost heaps.

Description: Body (dorsally and ventrally) uniformly reddish-yellow. Antennae and legs uniformly yellow-colored. Head very finely and sparsely punctate. Pronotum widest at midpoint, constricted basally and apically. Pronotum moderately finely and closely punctate, interspaces 1.0 times the diameter of punctures; pronotal base with a complete fine marginal line running along the bottom of the basal impression. Elytral punctation similar to pronotum (Fig. 8). Antennae: antennomere 1 short, straight, not or slightly expanded at apex, slightly longer than wide, approximately as long as antennomere 2; 3 slightly shorter than 2; 4-8 short and bead-like; antennal club distinct; antennomeres 9 and 10 transverse (Fig. 1.8). The smallest species of the genus; body width/length ratio, 0.40 ; length, $1.0-1.2 \mathrm{~mm}$.

\section{Atomaria testacea Stephens, 1830}

NEW BRUNSWICK: Albert Co.: Mary's Pt., August 12, 2004, C.G. Majka, coastal field, in compost (4, CGMC). NOVA SCOTIA: Cape Breton Co.: Scatarie Island: Savage Cove, August 10, 2005, K.R. Aikens, beach, under wrack (1, CBU); Colchester Co.: Bible Hill, May 31, 2005, June 14, 2005, K.R. Aikens, pasture, sweeping (4, CBU); Bible Hill, May 31, 2005, July 21, 2006, S.M. Townsend, sweeping (2, CBU); Bible Hill, June 3, 2007, June 15, 2007, August 1, 2007, C.W. D’Orsay, pasture, sweeping (5, CBU); Debert, June 19, 1993, J. Ogden (1, NSNR); Guysborough Co.: 
Dayspring Lake, 2-15 June, 1997, D.J. Bishop, red spruce, FIT (1, NSMC); Malay Lake, 14 May-2 June, 1997, 1-16 July, 1997, D.J. Bishop, red spruce (mature), FIT (2, NSMC); Seloam Lake, 14 May-2 June, 1997, 2-15 June, 1997, D.J. Bishop, red spruce, FIT (2, NSMC); Halifax Co.: Abraham's Lake, 1-16 July, 1997, D.J. Bishop, red spruce (old), FIT (1, NSMC); Anti Dam Lake, 1-16 July, 1997, D.J. Bishop, black spruce (90 years), FIT (1, NSMC); Antrim, June 9, 2005, J. Gordon, FIT (1, NSNR); Burnside, May 19, 2004, C. Cormier, field, on dead pig (1, SMU); Campbell Hill, 1530 June, 1997, D.J. Bishop, red spruce (mature), FIT (1, NSMC); Long Lake, May 25, 2002, C.G. Majka, along stream (1, CGMC); Pockwock Lake, 14 May-2 June, 1997, D.J. Bishop, red spruce (mature), FIT (1, NSMC); Pogwa Lake, 15-30 June, 1997, D.J. Bishop, red spruce, FIT (1, NSMC); Pt. Pleasant Park, July 2, 2001, July 7, 2001, August 18, 2001, June 9, 2002, June 18, 2002, July 23, 2002, C.G. Majka, red spruce forest, boggy area (6, CGMC); Sandy Lake, 16-29 July, 1997, D.J. Bishop, red spruce (120+ years), FIT (1, NSMC); south-end Halifax, May 26, 2001, May 20, 2002, June 21, 2002, C.G. Majka, open area (3, CGMC); south-end Halifax, August 22, 2002, C.G. Majka, compost (1, CGMC); Kings Co.: Kentville, August 10, 2005, July 9, 2006, August 19, 2007, D.H. Webster, compost (11, DHWC); Kentville, August 12, 2007, D.H. Webster, at light (1, DHWC).

Atomaria testacea is newly recorded in New Brunswick, Nova Scotia, and Canada (Fig. 15). In North America it has previously been recorded from southern California (Leng 1920) under the name Atomaria ruficornis Marsham, 1802, synonymized by Johnson et al. (2007). LeConte $(1869,258)$ reported a species from South Carolina under the name of Atomaria testacea Zimmerman; however, as Bousquet (1989) makes clear, this refers to Cryptophagus ferrugineus Sahlberg. In the Palaearctic region it is found throughout Europe, in Algeria, Morocco, and Tunisia in North Africa, and in Asia in Turkey, Kazhakhstan, Mongolia, and western Siberia (Johnson et al. 2007). In Atlantic Canada it has been found in red spruce forests, boggy areas and marshes, in pastures, fields, meadows, and open areas, on beaches under wrack, in a ravine, and in compost. Johnson (1993) reported that it was, "mainly a grassland species which has been recorded around farms, gardens and parks, but it often occurs in other habitats. It has been collected in man-made heaps of refuse, especially cut vegetation, grass, hay, haystack bottoms and compost, more rarely in dung or dung heaps."

Description: Head and prontotum piceous. Elytra piceous basally, gradually becoming paler in the apical half. Venter: pro-, meso-, and meta-sterna piceous; abdominal sterna and legs dark testaceous. Head finely, moderately sparsely, punctate. Pronotum and elytra moderately finely and densely punctate, interspaces 1.0-1.5 times the diameter of punctures, elytral punctures becoming finer apically; pronotum widest at midpoint, constricted towards base and apex; base with only a very shallow transverse impression (Fig. 9). Antennae: antennomere 1 swollen, slightly curved and expanded at apex; 2 smaller than 1 but also apically expanded; 3 almost as long as 2 and only slightly more slender; 4-8 short and somewhat bead-like; antennal club distinct; antennomeres 9 and 10 transverse (Fig. 1.8). Body: width/length ratio, 0.46; length, $1.3-1.6 \mathrm{~mm}$. 


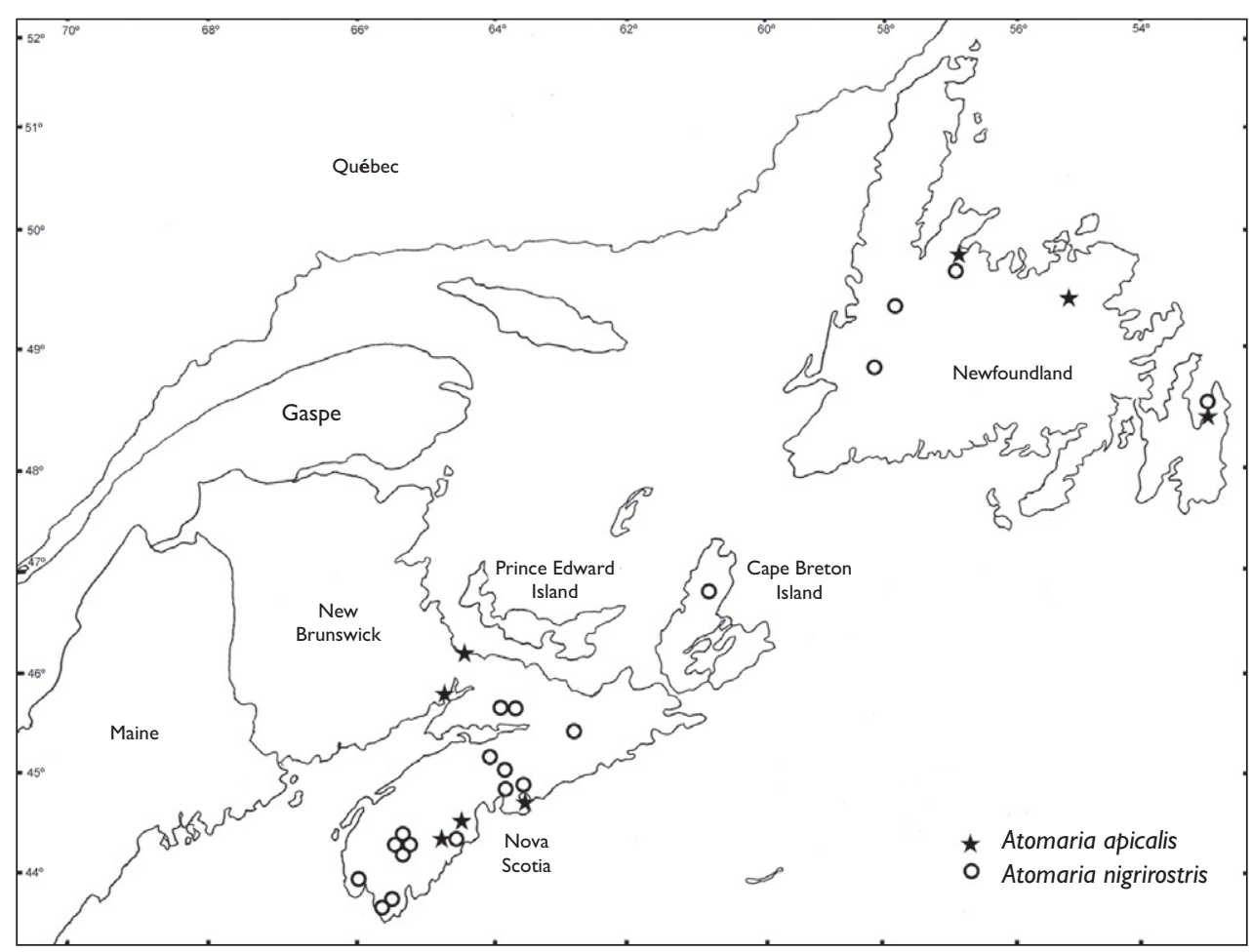

Figure 16. Distribution of Atomaria apicalis and Atomaria nigrirostris in Atlantic Canada.

Atomaria (s. str.) Stephens, 1829

\section{Atomaria nigrirostris Stephens, 1830}

LABRADOR: Middle Brook, June 2-17, 2005, July 4-18, 2005, S. Pardy, boreal forest, pitfall (5, MUN); Ossak Camp, June 28-July 11, 2004, S. Pardy, subarctic black forest, pitfall (1, MUN). NEWFOUNDLAND: Portugal Cove: Indian Meal Line, July 1, 1979, June 23, 1980 (2, AAFC); South Pond near South Brook, June 27, 1980, Brennan \& Larson, drift (2, AAFC); Little Grand Lake, 2 km E Martin Pond, June 8-July 13, 1993, old fir, pitfall (1, AAFC); Glide Lake, June 23, 1994, W. Bowers et al. (1, CFS). NOVA SCOTIA: Annapolis Co.: Big Dam Lake, June 27-July 7, 2004, H. Love, eastern hemlock forest (2, CGMC); Cumberland Co.: Wentworth, May 21July 5, 1965, B. Wright (1, NSMC); Wentworth Park, July 12, 1993, J. \& T. Cook, car net (2, JCC); Westchester-Londonderry, July 20, 1992, S. \& J. Peck, forest road, car net (5, JCC); Guysborough Co.: Trafalgar, Liscomb Sanctuary, July 19, 1992, S. \& J. Peck, car net (9, JCC); Halifax Co.: Long Lake, May 25, 2002, C.G. Majka, along stream (1, CGMC); Pockwock Lake, 2-15 June, 1997, D.J. Bishop, red spruce (mature), FIT (1, NSMC); Upper Tantallon, Indian Lake Rd., July 17, 1992, S. \& J. Peck, 
car net (1, JCC); Hants Co.: Frenchmen's Cave, July 2, 1998, M. Moseley, gypsum sinkhole (1, CGMC); Queens Co.: Caledonia, July 25, 1992, J. \& F. Cook, interior mixed forest, car net (4, JCC); Medway River, July 13, 1993, J. \& T. Cook, car net (15, JCC); North Cranberry Lake, August 13-24, 2004, June 28-July 8, 2004, H. Love, eastern hemlock forest (2, CGMC); Shelburne Co.: Clyde River Rd, July 16, 1992, S. \& J. Peck, forest, car net (4, JCC); Yarmouth Co.: Wellington, June 1-7, 1999, J. \& F. Cook, mixed coastal forest, FIT (3, JCC); Yarmouth-Shelburne: Oak Park Rd., August 27, 1992, J. \& F. Cook, car net (3, JCC).

Atomaria nigrirostris is newly recorded in Labrador, insular Newfoundland, Nova Scotia, and Canada (Fig. 16, 17). In North America, it has previously been recorded in Alaska (Leng 1920; Bousquet 1991) under the name Atomaria fuscicollis Mannerheim, 1852, synonymized by Johnson et al. (2007). In the Palaearctic region it is found throughout Europe (including Turkey), in Algeria in North Africa, across Siberia to the Russian Far East, south to Mongolia, and in central Asia in Iran and Uzbekistan (Johnson et al. 2007). In Atlantic Canada it has been collected in eastern hemlock, red spruce, and mixed forests, along a stream, and in a gypsum sinkhole. Lohse (1967) reported it in Europe from along rivers, under leaves. Johnson (1993) reported that it was, "a woodland species, mostly associated with broadleaved trees, it occurs on and under dead wood on the ground, in moss, leaf litter, flood refuse and general ground litter. It also occurs under hedgerows."

Description: Head, pronotum, and pro-, meso-, and meta-sterna piceous brown; elytra and abdominal sterna a slightly paler, fuscous brown; elytra becoming slightly paler in apical half. Head, pronotum, and elytra moderately densely, moderately strongly punctate; interspaces 1.0-1.5 times the diameter of punctures; apex of elytra slightly more finely punctate; elytral setae approximately the length of the interspaces, prominent and somewhat erect. Pronotum strongly constricted from midpoint to apex, parallel from midpoint to pronotal base; before base with a strong transverse impression, with several fine and sharp longitudinal ridges. Elytra scarcely, or not, wider than pronotum (Fig. 10). Antennae: antennomere 1 long and curved, twice as long as 2 and approximately twice as wide at apex than at base; 2 cylindrical; 3 as long as 2 but more slender; 4, 6, and 8 short and bead-like; 5 and 7 somewhat longer; club distinct; antennomeres 9 and 10 clearly transverse (Fig. 1.7). Body: width/length ratio, 0.31 ; length, $1.7-1.9 \mathrm{~mm}$.

\section{Atomaria wollastoni Sharp, 1867}

LABRADOR: Middle Brook, June 17-July 4, 2005, July 18-2 August, 2005, August 24-September 12, 2005, S. Pardy, boreal forest, pitfall (3, MUN); Muskrat Falls, June 2-17, 2005, S. Pardy, boreal forest, pitfall (1, MUN); Ossak Camp, June 28-July 11, 2004, August 11-29, 2004, September 22-October 8, 2004, S. Pardy, subarctic black forest, pitfall (19, MUN); St. Lewis, August 25-September 7, 2004, S. Pardy, heath, pitfall (1, MUN). NEWFOUNDLAND: Picadilly, July 7, 1949, E. Palmen 


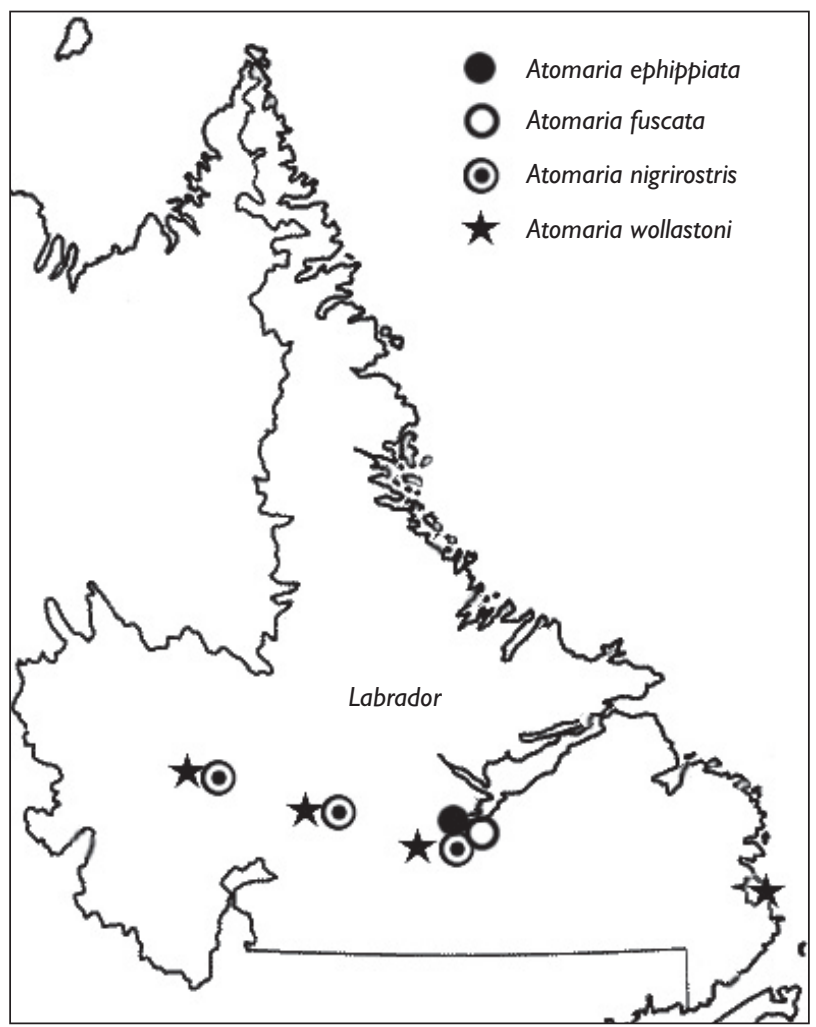

Figure 17. Distribution of Atomaria ephippiata, Atomaria fuscata, Atomaria nigrirostris, and Atomaria wollastoni in Labrador.

(1, MZHF); Cape Broyle, June 8, 1949, E. Palmen (1, MZHF); South Branch, July 3, 1949, E. Palmen (1, MZHF); Corner Brook, Cooks Pond Lower, June 24-July 15, 1992, 40 year old fir forest (3, MUN); Conception Bay, May 18, 1980 (1, MUN); Manuals R., 8 km W of St. John's, June 10, 1984, D. Langor (1, MUN); Portugal Cove: Indian Meal Line, May 16, 1979, June 2, 1979, July 1, 1979, October 20, 1980, May 28, 1981, June 22, 1981, July 19, 1981, September 1, 1981, July 21, 1982 (28, MUN); St John's, Oxen Pond Botanical Garden, September 5, 2000, D. Larson (1, MUN); Gander, T.H. Howe Forest, July-August, 1998, D. Russell, wind drift (1, MUN); Red Indian Lake, June 25, 1980, Brennan \& Larson, drift (1, MUN); South Pond near South Brook, June 27, 1980, Brennan \& Larson (4, MUN); Little Grand Lake, Bakeapple Brook, June 24-July 15, 1992, old fir, pitfall (3, MUN); Glide Lake, July 5, 1994, W. Bowers et al. (1, MUN); Glide Lake, June 20, 1996, pitfall (2, CFS); Glide Lake, July 19, 1996, August 22, 1996, pitfall (2, MUN); Glide Lake, August 30, 1994, pitfall (1, CFS); Pasadena, May 16, 1988, L.H. Hollett (2, MUN). NOVA SCOTIA: Annapolis Co.: Durland Lake, June 6, 2003, P. Dollin, eastern hemlock/ balsam fir/black spruce (120+ years), under bark of $\log (1$, NSMC); Cumberland Co.: Wentworth Park, July 12, 1993, J. \& T. Cook, car net (1, JCC); Halifax Co.: Halifax, 
May 26, 2009, S. MacIvor, open area (1, SMU); Big Indian Lake, June 11, 2003, P. Dollin, red spruce (80-120 years), red spruce stump (2, NSMC); Queens Co.: Fifth Lake Bay, July 13, 2003, P. Dollin, hemlock (120+ years), pitfall (1, NSMC); Medway River, July 13, 1993, J. \& T. Cook, car net (5, JCC); Sixth Lake, June 20, 2003, P. Dollin, eastern hemlock (120+ years), funnel trap (1, NSMC); Yarmouth Co.: Carleton: Perry Rd., July 18, 1993, J. \& T. Cook, car net (1, JCC).

Atomaria wollastoni is newly recorded in Labrador, insular Newfoundland, and Nova Scotia (Fig. 13, 17). Dollin et al.'s (2008) records of A. ochracea are attributable to A. wollastoni. Leng (1920) reported it from "Canada." In Europe this species has a northern distribution having been recorded in central and northern Russia, Scandinavia, Estonia in the Baltic region, Great Britain, Ireland, the Netherlands, Germany, and France (Johnson et al. 2007). In Atlantic Canada it has been found in coniferous forests consisting of eastern hemlock, balsam fir, red spruce, and black spruce (Picea mariana (Mill.) BSP., Pinaceae). In Europe, Schiegg (2000) classed it as a stenotopic saproxylic species characteristic of high dead wood connectivity, and noted that it is red-listed in Germany. It is also red-listed in Denmark (Stolze and Pihl 1997). In Norway, Hågvar (1999) found it associated with sporocarps of Fomitopsis pinicola (Fr.) Karst. (Polyporaceae). It would appear to be a characteristic saproxylic species in both Europe and North America.

Description: Head and pronotum blackish-piceous; elytra, antennae, and legs testaceous. Venter piceous. Head, pronotum, and elytra moderately densely, moderately strongly punctate; interspaces 1.0-1.5 times the diameter of punctures; apex of elytra slightly more finely punctate. Elytral setae approximately the length of the interspaces, appressed. Pronotum widest at approximately the middle, evenly arcuately constricted to apex and base, hind angles rounded; base of pronotum without transverse impression (Fig. 11). Antennae: antennomere 1 long and curved, twice as long as 2 and approximately twice as wide at apex than at base; 3, 5 and 7 shorter and more slender; 4, 6, and 8 short and bead-like; club moderately distinct; antennomeres 9 and 10 quadrate (Fig. 1.10). Body: width/length ratio, 0.33; length, 1.5-1.8 mm.

\section{Discussion}

As a result of the present investigation, ten species of Atomaria have been recorded in Atlantic Canada. Of these, six including Atomaria distincta, A. fuscata, A. lederi, A. lewisi, A. testacea, and A. nigrirostris are newly recorded in Canada. Atomaria lederi and A. lewisi are newly recorded in North America.

The paucity of knowledge about many of these species in North America, makes determination of the zoogeographic status of some species uncertain (Table 1). Two species, Atomaria ephippiata and A. distincta, are clearly Nearctic, not having been recorded outside this region. Atomaria apicalis and $A$. pusilla, have previously been categorized as "probably" adventive Palaearctic species by Bousquet (1991). The designation of Atomaria apicalis, however, was prior to the synonymy with the Nearc- 
tic Atomaria ovalis (in the present study); consequently this designation needs to be re-evaluated since the wide distribution of $A$. apicalis is more indicative of a native Holarctic species. Atomaria fuscata has a wide distribution in North America on both Pacific and Atlantic coasts, and in the interior of the continent, also suggestive of a native Holarctic species. The northern boreal distributions of Atomaria lederi and A. wollastoni in the Palaearctic region could be indicative of species with a Holarctic distribution. However, there are very few records of these species in North America. Atomaria nigrirostris is widely distributed in the Palaearctic region, and records in North America (Alaska, Labrador, Newfoundland, and Nova Scotia) are consistent with a Holarctic distribution. Atomaria lewisi and $A$ testacea are widely distributed in the Palaearctic region, but have only been reported from a limited number of locations in North America - possibly indicative of adventive species on this continent. Given the limited knowledge about this genus in North America, and the considerable taxonomic confusion that still exists, the zoogeographic status of all these species should be re-evaluated in the future when more information is available and the genus is better understood.

Within Atlantic Canada, few generalizations can be made with respect to the distribution of species as indicated in Figs 13-17. Atomaria apicalis, A. ephippiata, A. fuscata, A. nigrirostris, and $A$. wollastoni are represented by a substantial number of records and appear to be relatively widely distributed throughout Atlantic Canada (Figs 13, 16). All but $A$. apicalis are also found in southern Labrador (Fig. 17). Atomaria lederi, A. lewisi, and $A$. testacea are represented by a moderate number of records and generally distributed in Nova Scotia (although A. lewisi has not been found on Cape Breton Island), and the latter two species have additionally been collected in New Brunswick (Figs 14, 15). Atomaria distincta, and $A$. pusilla are represented by a small number of records and appear to be relatively restricted in their distribution (Figs 14, 15). However, collecting effort for this genus has been far from adequate in all areas of the region, with the possible exception of the mainland of Nova Scotia. Consequently generalizations about their distribution or abundance in the region must be provisional. The possibility of additional species occurring in the region has certainly not been excluded. Further collecting is clearly indicated in order to gain a better understanding of the members of this genus in Atlantic Canada.

It is evident that there are differences in habitat preferences amongst these species. Atomaria ephippiata, A. fuscata, A. lewisi, and A. testacea appear to be eurytopic species found in a wide variety of forested and open habitats; Atomaria lederi and A. wollastoni have been principally collected in coniferous forests, whereas Atomaria nigrirostris has been found in coniferous, deciduous, and mixed forests. All three appear to be primarily saproxylic species. Atomaria apicalis, A. distincta, and A. pusilla are all primarily found in grasslands and other open habitats. Atomaria fuscata, A. ephippiata, A. lewisi, and $A$. testacea have all been collected in compost heaps in this region, and $A$. distincta, A. fuscata, A. ephippiata, and $A$. testacea have all bean found in seashore, salt marsh, and beach drift environments. At least in Great Britain and Ireland, A. pusilla appears to be primarily a synanthropic species (Johnson 1993). Further bionomic investigations should be conducted to better understand the macro- and micro-habitat preferences of these species and the ecological roles that they play in their respective environments. 


\section{Acknowledgements}

Sincere thanks to Susan Westby (formerly with Agriculture and Agri-Food Canada, Kentville), Christine Noronha and Mary Smith (Agriculture and Agri-Food Canada, Charlottetown), Kathleen Aikens, Clayton D’Orsay, Andrew MacDonald, David McCorquodale, and Sheena Townsend (Cape Breton University), Joyce Cook (Carleton University), Philana Dollin (Dalhousie University), Jens Esser (Berlin), David Larson (formerly at Memorial University), Shelley Pardy Moores (Newfoundland Department of Environment and Conservation), Jeff Ogden (Nova Scotia Department of Natural Resources), Chantelle Cormier and Scott MacIvor (Saint Mary's University), Gary Hevel (Smithsonian Institution), Jean-Philippe Michaud (Université de Moncton), Olof Biström (Zoological Museum, University of Helsinki, Finland), DeLancey Bishop, David H. Webster, and Reginald P. Webster for making specimens, records, and information available. We thank two anonymous reviewers for their constructive suggestions. The first author thanks David Christianson, Calum Ewing, and Andrew Hebda at the Nova Scotia Museum for continuing support and encouragement. This work has been assisted by the Board of Governors of the Nova Scotia Museum.

\section{References}

Blatchley WS (1910) An illustrated descriptive catalogue of the Coleoptera or beetles (exclusive of the Rhynchophora) known to occur in Indiana. The Nature Publishing Company, Indianapolis, Indiana, $1386 \mathrm{pp}$.

Bousquet Y (1989) A review of the North American genera of Cryptophaginae (Coleoptera: Cryptophagidae). The Coleopterists Bulletin 43(1): 1-17.

Bousquet Y (1991) Family Cryptophagidae: silken fungus beetles. In: Bousquet Y (Ed) Checklist of Beetles of Canada and Alaska. Agriculture Canada: Research Branch Publication 1861/E, 221-223. http://www.canacoll.org/Coleo/Checklist/PDF\%20files/CRYPTOPHAGIDAE.pdf [accessed 11.XI.2009]

Britton WE (1920) Check-list of the Insects of Connecticut. State Geological and Natural History Survey Bulletin of Connecticut 31. Hartford, Connecticut. 397 pp.

Casey TL (1900) Revision of the North American Cryptophagidae. Journal of the New York Entomological Society 8: 75-128.

Chandler DS (2001) University of New Hampshire Insect and Arachnid Collections. http:// insectcoll.unh.edu/ [accessed 11.XI.2009]

Dollin PE, Majka CG, Duinker PN (2008) Saproxylic beetle (Coleoptera) communities and forest management practices in coniferous stands in southwest Nova Scotia. In: Majka CG, Klimaszewski J (Eds) Biodiversity, Biosystematics, and Ecology of Canadian Coleoptera. ZooKeys 2: 291-336. http://pensoftonline.net/zookeys/index.php/journal/article/ view/15/44 [accessed 11.XI.2009]

Downie NM, Arnett RH, Jr (1996) The Beetles of Northeastern North America. Sandhill Crane Press. Gainsville, Florida, 1721 pp. 
Evenhuis NL (2009) Abbreviations for insect and spider collections of the world. Available from: http://hbs.bishopmuseum.org/codens/codens-inst.html [accessed 4.VIII.2009]

Hågvar S (1999) Saproxylic beetles visiting sporocarps of Fomitopsis pinicola and Fomes fomentarius. Norwegian Journal of Entomology 46: 25-32.

Hammond HEJ, Langor DW, Spence JR (2001) Early colonization of Populus wood by saproxylic beetles (Coleoptera). Canadian Journal of Forest Research 31(7): 1175-1183.

Hatch MH (1961) The beetles of the Pacific Northwest, Part III: Pselaphidae and Diversicornia I. University of Washington Press, Seattle, Washington, 503 pp.

Jacobs JM, Spence JR, Langor DW (2006) Influence of boreal forest succession and dead wood qualities on saproxylic beetles. Agricultural and Forest Entomology 9(1): 3-16.

Johnson C (1970) Three new species of Atomaria Stephens (Coleoptera: Cryptophagidae) from the eastern Palaearctic. Notulae Entomologicae 50: 112-116.

Johnson C (1971) Atomariinae (Col., Cryptophagidae) from the northern parts of the Indian sub-continent with descriptions of seven new species. Entomologists Monthly Magazine 107 [1970]: 224-232.

Johnson C (1992) Cryptophagidae. In: Freude H, Harde KW, Lohse GA (Eds) Die Kafer Mitteleuropas, Band 13. Goecke \& Evers, Krefeld, Germany, 119-133.

Johnson C (1993) Provisional atlas of the Cryptophagidae-Atomariinae (Coleoptera) of Britain and Ireland. Biological Records Centre, Natural Environmental Research Council, Institute of Terrestrial Ecology, Huntingdon, Cambridgeshire, Great Britain. 91 pp. http:// nora.nerc.ac.uk/7280/1/Cryptophagidae-Atomarinae.pdf [accessed 11.XI.2009]

Johnson C, Otero JC, Leschen RAB (2007) Cryptophagidae Kirby, 1837. In: Löbl I, Smetana A (Eds) Catalogue of Palaearctic Coleoptera, Volume 4: Elateroidea, Derontoidea, Bostrichoidea, Lymexyloidea, Cleroidea, Cucujoidea. Apollo Books, Stenstrup, Denmark, 513-531.

LaBonte JR (1998) Terrestrial riparian arthropod investigations in the Big Beaver Creek Research Natural Area, North Cascades National Park Service Complex, 1995-1996: Part II, Coleoptera. United States Department of the Interior Technical Report NPS/NRNOCA/ NRTR/98-2. United States Department of the Interior, Washington, DC, 18 pp.

LeConte JL (1869) Synonymical notes on Coleoptera of the United States, with descriptions of new species, from the mss. of the late Dr. C. Zimmerman. Transactions of the American Entomological Society 2: 243-259.

Leng CW (1920) Catalogue of the Coleoptera of America north of Mexico. John D. Sherman, Jr., Mount Vernon, New York, 470 pp.

Leschen RAB, Skelley PE (2002) Cryptophagidae Kirby 1837. In: Arnett RH, Jr, Thomas, MC, Skelley PE, Frank JH (Eds). American Beetles, Volume 2: Polyphaga: Scarabaeoidea through Curculionoidea. CRC Press, Boca Raton, USA, 338-342.

Lohse GA (1967) Fam. Cryptophagidae. In: Freude H, Harde KW, Lohse GA. (Eds) Die Käfer Mitteleuropas, Band 7: Clavicornia. Goecke \& Evers, Krefeld, Germany, 110-157.

Majka CG, Shaffer F (2008) Beetles (Coleoptera) in the diet of Piping Plovers in the Iles de la Madeleine, Québec, Canada. Wader Study Group Bulletin, 115(2): 77-83. 
Notman H (1920) Coleoptera collected at Windsor, Broome Co., N. Y., 26 May to 5 June, 1918, with notes and descriptions. Journal of the New York Entomological Society 28(2): 178-194.

Oatman ER, Legner EF, Brooks RF (1964) An ecological study of arthropod populations on apple in northeastern Wisconsin: insect species present. Journal of Economic Entomology 57(6): 978-983.

Poole RW, Gentili, P (Eds) (1996) Nomina Insecta Nearctica: A Check List of the Insects of North America. Vol. 1: Coleoptera, Strepsiptera. Entomological Information Services, Rockville, Maryland, 827 pp. http://www.nearctica.com/nomina/main.htm [accessed 11.XI.2009]

Procter W (1946) Biological Survey of the Mount Desert Region, Part VII: The Insect Fauna. Wistar Institute of Anatomy and Biology, Philadelphia, Pennsylvania, 566 pp. http://www. biodiversitylibrary.org/item/29157 [accessed 11.XI.2009]

Sikes DS (2004) The beetle fauna of Rhode Island: an annotated checklist. Rhode Island Natural History Survey, Volume 3. Kingston, Rhode Island, 296 pp.

Schiegg KG (2000) Are there saproxylic beetle species characteristic of high dead wood connectivity? Ecography 23: 579-587.

Schwert DP (1996) Effect of Euro-American settlement on an insect fauna: paleontological analysis of the recent chitin record of beetles (Coleoptera) from northeastern Iowa. Annals of the Entomological Society of America 89(1): 53-63.

Sjöberg O (1947) Die Ergebnisse einer Genitaluntersuchung der nordischen Arten der Gattung Atomaria Steph. (Col., Cryptophagida). Entomologisk Tidskrift 69: 91-119.

Stoltze M, Pihl, S (1997) Rødliste 1997 over plantewr og dyr I Danmark. Miljø- og Energiministeriet, Danmarks Miljøundersøgelser, Skov- og Naturstyrelsen. København, Danmark, 220 pp. http://www.sns.dk/udgivelser/1997/rodliste/rodlis.pdf [accessed 11.XI.2009]

Williams RN, Ellis MS, Fickle DS (1995) Insects in the Killbuck Marsh Wildlife Area: 1993 Survey. Ohio Journal of Science 95(3): 226-232. 